European Journal of Accounting, Auditing and Finance Research

Vol.8, No. 6, pp.28-45, May 2020

Published by ECRTD-UK

Print ISSN: 2053-4086(Print), Online ISSN: 2053-4094(Online)

\title{
EFFECT OF MARKET RISKS ON THE FINANCIAL PERFORMANCE OF FIRMS IN NIGERIA
}

\section{Augustine Odubuasi*}

\author{
Wilson-Oshilim, Uduak Deborah**
}

\section{Prof. Meshack Ifurueze ${ }^{* * *}$}

*Ph.D Student of Chukwuemeka Odumegwu Ojukwu University, Igbariam (Correspondence author)

**Ph.D Student of Chukwuemeka Odumegwu Ojukwu University, Igbariam ***Professor of Accounting, Chukwuemeka Odumegwu Ojukwu University, Igbariam

\begin{abstract}
Business operations are surrounded by different degrees of uncertainties (risks) ranging from market risks, financial risks and operating risks. This study has chosen to investigate one of the components of the risks (market risk) and to ascertain how the risks affect the activities of firms in Nigeria. Four hypotheses were formulated in line with the objectives of the study. The study employed causal research design and used secondary data. The research covers the twelve (12) firms listed under Oil and Gas sector on the Nigerian Stock Exchange. Secondary data were collected from Central Bank of Nigeria Statistical Bulletin and the financial statements of the firms which spanned from 2014 to 2018. The data were analysed with descriptive statistics, correlation and multiple regression analysis. The results therefrom indicate that exchange rate has significant effect on both ROA and ROE of Oil and Gas firms. Additionally interest rate has significant effect on ROE and insignificant effect on ROA. More results show that commodity price change has no significant effect on both ROA and ROE, also equity price change has no significant effect on ROA and ROE of firms in Oil and Gas sector in Nigeria. The study recommends among other things that the firms should adopt the use of hedging to control exchange rate changes and government should maintain a low interest rate that will aid firms increase their profitability.
\end{abstract}

KEYWORDS: market risk, oil price, exchange rate

\section{INTRODUCTION}

Business entities in Nigerian economy are surrounded by uncertainties (risk) in their operations which they must surmount before they can survive or become successful. Kanchu and Kumar (2013) see risk as anything limiting the achievement of a certain predefined objectives. Some of those risks include financial risks, operating risks and market risks. Market risks being the subject of this study is however, the risk of an entity resulting from movements in market prices which consists changes in interest rates, foreign exchange rates, equity and commodity prices (Muriithi, Muturi \&Waweru, 2016; Ekinci, 2016). The degree of deepeness of market risk as it affects performance of business organisations threw up a rhetorical question on how the risk operates. The risk can trigger off losses quickly in a volatile market conditions. 
European Journal of Accounting, Auditing and Finance Research

Vol.8, No. 6, pp.28-45, May 2020

Published by ECRTD-UK

Print ISSN: 2053-4086(Print), Online ISSN: 2053-4094(Online)

The operation of Oil and Gas industry in Nigeria is not in isolation of exposure to market risk. This industry is important as Nigeria is one of the top oil and gas producers in Africa and has the continent's largest natural gas reserves. The Oil and gas industry being the mainstay of Nigerian economy plays a vital role in shaping the economic and political destiny of the nation (Odularu, 2008). Nigeria as the economic driving force in West Africa is because of its richness in fossil fuels that has the major influence in its revenue generation. Nigeria neglected its strong agricultural produce sequel to the oil booms in the 1970's. By the year 2000, oil and gas contributed about $83 \%$ revenue to federal government and accounted for $98 \%$ of federal government's export earnings (Odularu, 2008). National Bureau of Statistics (2017) reported that Oil and Gas industry in Nigeria accounted for approximately $70 \%$ of government's revenue and more than $90 \%$ of its exports earnings. The influence of oil and gas became glaring when fall in oil price by $66.8 \%$ per barrel from $\$ 114 \mathrm{pb}$ as recorded in June 2014 to $\$ 38.0$ per barrel by December 2015 was purported to be the major reason for the recent Nigeria's recession encounter (NBS, 2016). In the 2016 financial year, oil price further dropped to $\$ 32.6$ per barrel as at $3^{\text {rd }}$ February, towards November 2016, oil price rose to $\$ 40.68$ per barrel. In 2017 price of oil was $\$ 52.51$, this was exactly when it was reported that Nigeria had started coming out of recession. By 2018, the oil price has increased to $\$ 69.42$ per barrel, in which case, the Nigerian economy was said to have completely overcome recession (Statista, 2018).

Many researchers in Nigeria and beyond had actually studied on the various risks that hamper the smooth operations of the financial sector of the economy. The likes of Oyerogba and Ogunlade (2016) looked at links between risks and financial sector in Nigeria, Ekinci (2016) studied same at Turkey, and Muriithi, Muturi and Waweru, (2016) carried out a study of risks and bank performance in Kenya. These studies are anchored on financial sector as they perceived banking industry as the vehicle that links their economy to the rest of the world. However, since it is obvious that Oil and Gas sector is Nigeria's economy and Nigeria's economy is oil and Gas sector- meaning that they are like Siemens twins and an indispensable sector of the economy, it becomes imperative therefore to conduct studies on how market risk has influenced the performance of Oil and Gas industry in Nigeria.

\section{Objectives of the Study}

The broad objective of this study is to investigate the effect of market risks on the performance of Oil and Gas firm in the Nigeria. The study is set to achieve the following specific objectives; 1. To ascertain the effect of interest rate changes on the financial performance Oil and Gas industry in Nigeria,

2. To determine the effect of foreign exchange rate changes on the oil and Gas industry financial performance in Nigeria,

3. To ascertain the effect commodity prices changes on the financial performance of Oil and Gas industry in Nigeria.

4. To investigate the effect of equity price changes on the financial performance of Oil and Gas firms in Nigeria.

\section{Hypotheses}

The study tested the following hypotheses, formulated in line with the objectives, which are stated in their null forms as follows; 
European Journal of Accounting, Auditing and Finance Research

Vol.8, No. 6, pp.28-45, May 2020

Published by ECRTD-UK

Print ISSN: 2053-4086(Print), Online ISSN: 2053-4094(Online)

Ho1: Interest rate changes do not have significant effect on the financial performance of Oil and Gas industry in Nigeria,

Ho2: Foreign exchange rate changes do not have significant effect on the financial performance of Oil and Gas industry in Nigeria,

Ho3: Commodity price changes do not have significant effect on the financial performance of Oil and gas industry in Nigeria.

Ho4: Changes in equity do not have significant effect on the performance of Oil and Gas sector in Nigeria.

The study result will aid government understand the directional effect of change in interest rate on Oil and Gas sector and enable them use interest rate as a monetary policy tool to stimulate the economy for greater productivity. The result will also help management of Oil and Gas industry formulate policies that will be tailored towards those risks whose volatility generates great danger to the profitability of the firms. The remaining section is structured that section two is the review of related literature, section three is the methodology, section four and five are the data analysis and conclusion and recommendation respectively.

\section{REVIEW OF RELATED LITERATURE}

\section{Conceptual framework}

\section{Market Risk}

Market risk is the risk that a firm will incur losses because of a change in the price of assets held resulting from changes in interest rate, securities, commodity prices, foreign exchange rate and other market risk factors. Ekinci (2016) upholds that market risk is the risk of losses in liquid portfolio arising from the movements in market prices and consisting of interest rate, foreign currency, equity and commodity price risks. In the words of Ekinci (2016) and Namasake (2016), market risk exposure is more volatile than credit risk exposure because of rapid changes in market condition that can cause severe financial losses and possible collapse.

\section{Interest Rate Changes}

Interest rate is the price charges placed for the use of money, which is usually expressed as an annual percentage of the principal. The Central Bank of Nigeria $(\mathrm{CBN})$ regulates the Monetary Policy Rate (MPR), formerly minimum Rediscount Rate (MRR) which is official interest rate that anchors all other interest rate in the money market and economy (Ogunbiyi \& Ihejirika, 2014). Similarly Corb (2012) insists that interest rate is an economic tool used by CBN to control inflation and boost economic development.

\section{Commodity Price change}

Commodities are reasonably interchangeable goods or materials bought and sold freely as an article of commerce which includes agricultural products, fuels and metals that are traded in bulk on a commodity exchange or spot market (businessdictionary.com). Ildirar and Iscan (2015) opine that commodities consist of the basic materials and natural resources used in virtually all products and manufacturing process, notably among them are oil, wheat, iron and robber that are the main components of many common goods in our lives. Farooki and Kaplinsky (2012) classified commodities into industrial crops (Timber), Fisheries, Cereals, Beverages, Livestock, Precious metals, Coal and Petroleum products. The price changes of the 
European Journal of Accounting, Auditing and Finance Research

Vol.8, No. 6, pp.28-45, May 2020

Published by ECRTD-UK

Print ISSN: 2053-4086(Print), Online ISSN: 2053-4094(Online)

most important commodities in the worlds commodity exchange markets influence the price of local producers or imported productions (Algita \& Indre, 2014).

\section{Exchange rate risk}

The exchange rate is the price of one country's currency expressed in terms of another country's currency. Exchange rate has been noted to be the product of interaction between the demand for and supply of foreign exchange (Ezejelue, 2008; Enekwe, Ordu \& Nwoha, 2013), and in effect, Oladipupo and Onotaniyohuwo (2011) opine that exchange rate movements have ripple effects on the economic activities of a nation. Inevitably, exchange rate serves as the lubricating oil in the international transactions and in that case companies as well as nations get affected either favourably or unfavourably by the swings or fluctuations in exchange rate (Enekwe, Ordu \& Nwoha, 2013). Agubata and Odubuasi (2018) found exchange rate to have positive effect on performance of manufacturing companies in Nigeria..

\section{Equity price change}

Equity price is the amount of money which one may buy or sell a share of common stock in the stock market. Hence change in equity price is the variations that occur on the price of share throughout the day especially when demand and supply varies. Mustafa and Nishat (2006) posit that market equity price is volatile and sensitive in the sense that changes occur rapidly due to political upheavals. Musyoki (2011) pointed out that asides profitability indices, other variables that affect share price includes interest rates, inflation rate, government regulation and investors behaviour.

\section{Financial Performance}

Financial performance is a post business operation activity to determine how economically well or profitable the business has done within a particular period. In other words, financial performance is the extent to which financial goals or obligation of a firm is being accomplished. To determine the financial position of a firm, Irungu (2013) posits that financial performance analysis is conducted to identify the financial strengths and weaknesses of the firms by using and establishing relationship between items of the financial position and income statement. The financial performance is commonly measured by the ratios such as return on equity, return on assets, return on capital, return on sale and operating margin (Gilchris, 2013; and Ismail 2011). More so, Return on Assets (ROA) and Return on Equity (ROE) ratios are the two key financial performance indicator commonly used to measure firms' performance quite effectively (Price Water House Coopers, 2008; Zaman, Arslan, Sohail \& Malik, 2014).

\section{THEORETICAL FRAMEWORK}

\section{Capital Assets Pricing Model (CAPM)}

The Capital Assets Pricing Model (CAPM) is a theory that targets to measure the relationship between the systematic risk of a security or portfolio and its expected return. The theory was propounded by Sharpe (1964) and Lintner (1965). Though it was a development on the portfolio model built by Markowtiz (1952), by adding two assumptions which say that; oneinvestors are risk averse, two- when choosing among portfolios, investors care only about the mean and variance of their one period investment return (Rossi, 2016). In CAPM, total risks associated with an asset can be split up in two components; systematic (non-diversifiable) and 
European Journal of Accounting, Auditing and Finance Research

Vol.8, No. 6, pp.28-45, May 2020

Published by ECRTD-UK

Print ISSN: 2053-4086(Print), Online ISSN: 2053-4094(Online)

unsystematic (diversifiable) risk (Noor \& Abdalla, 2014). The risk that is of importance or relevance to CAPM is the systematic (non-diversifiable) risk which affects all assets traded on the market and is related to political, social and economic variables (Rodriguez-Moveno \& Pena, 2013). Similarly, Hull (2015) posits that systematic risk is associated with asset price behavior in relation to market fluctuations and may be subdivided into stock price risk, foreign exchange risk, interest rate risk and commodity price risk. Pertinently, the CAPM shows that investors only get compensated for holding systematic risk, since the firm specific component of risk can be eliminated through diversification (Monda, Giorgino \& Modolin, 2013). The CAPM holds that the expected return on any asset ${ }_{i}$ is the risk-free interest rate $\left(R_{f}\right)$ plus a risk premium, which is the assets market beta $\left(\mathrm{B}_{\mathrm{im}}\right)$, times the premium per unit of beta risk, $\mathrm{E}(\mathrm{Rf})$ Rf. Put mathematically, we have $\left.E\left(R_{f}\right)=R_{f}+\left[E\left(R_{m}\right)-R_{f}\right)\right] B_{i m}$. In other words, Sharpe (1964) and Lintner (1965) suggest that systematic risk, risk free rate and anticipated risk market quality plays a much bigger role in determining the price or expected return on asset. Since the market risks is tantamount to undiversifiable risk, the theory then presents a bases of ascertaining the ability of the firms in Oil and Gas sector to whittle down these uncertainties, to remain profitable still in their operations.

\section{Empirical Review}

Harley (2018) empirically examined the effect of exchange rate fluctuations on the performance of some firms listed on the Nigeria stock exchange market. The study used Ordinary Least Square (OLS) regression technique on the panel data generated from 2012 to 2016. They found that exchange rate fluctuation possess a significant positive impact on the returns on investment of the firms sampled.

Ihsan, Rashid and Naz (2018) made an assessment on the relationship between exchange rate exposure and firm value on domestic firms comparatively with multinational firms (all nonfinancial firms) listed on the Pakistan Stock Exchange (PSE). The sample of the unbalanced Panel data of the 232 selected nonfinancial firms were collected, from Pakistan Stock Exchange and the State Bank of Pakistan Statistical Bulletin, for fifteen years covering 2000 to 2014 from and generalized least square estimator was applied to overcome the problem of heteroskedasticity. Their results show that exchange rate variations have a significant effect on the firm value and firms are exposed significantly to one-period lagged variation in the exchange rate. More so, the findings disclose that multinational firms experience greater exchange exposure in comparison with domestic firms.

Agubata and Odubuasi (2018) investigated the effect of exchange rate fluctuation on the financial performance of manufacturing firms in Nigeria, sampling the eight firms within the food, beverage and tobacco sector of the economy. Ex post facto research design was employed and time series data of the samples were collected from central Bank of Nigeria Statistical Bulletin and the financial statements of the firms which spanned from 2005 to 2014. Ordinary Least Square (OLS) multiple regression estimator was used and the results indicate that exchange rate and inflation rate have positive effect on the financial performance of the sector where as interest rate has negative effect on the food, beverage and tobacco sector.

Darko and Kruger (2017) found that crude oil prices have positive and significant impact on the accounting returns (ROA, ROE and EPS) of the reviewed firms. Their study was prompted 
European Journal of Accounting, Auditing and Finance Research

Vol.8, No. 6, pp.28-45, May 2020

Published by ECRTD-UK

Print ISSN: 2053-4086(Print), Online ISSN: 2053-4094(Online)

by the fact that earlier investigations into the effect of crude oil fluctuations had been on country by country bases, and they demanded to ascertain how the result will be when the major oil companies of the world, which would cut across countries, feel the effect of changes in the crude oil prices on their profitability. Their study covered top 20 oil and gas companies from 2012 to 2016 as was reported by Forbes annual reports of 2016, but panel data was collected from the 8 of the companies that reported their accounts on the IFRS formats. The data was analysed using (OLS) panel regression model, random effect and fixed effect estimation to establish the cause effect relationships between the explained and the explanatory variables.

Risman, Salim, Sumiati and Indrawati (2017) evaluated the effect of commodity prices (crude oil, coal, crude palm oil, gold, nickel and tin), exchange rate and investment on the firms' value, either directly or indirectly through mediation of business risk. The study covers a sample of 25 mining and agricultural firms listed on the Indonesian Stock Exchange spanning through 2010 to 2014 that gives a panel balanced data of 5 years, which generated 125 observations. A Path Analysis was developed which concurred with the regression model adopted for the study. The result obtained by applying common effect approach for panel data on the path analysis model indicate that oil prices and exchange rate affect the firms value either directly or indirectly through business risk as mediation variable, but risk does not mediate the effect of the investment on the firms' value.

Bagirov and Mateus (2017) expanded the understanding of the relationship between oil prices, stock markets and firm performance on Europe stock market. Their study was in three stages; firstly they investigated the effect of oil price changes on the European Stock Market. Next, they evaluated the spillover volatilities between oil price and Stock Market in Europe. The study was also conducted on market level and sector level. Finally, they examined the impact of crude oil price changes on the financial performance measure of oil and gas firms, both listed and unlisted from the Western European region. Their results indicate the presence of one directional relationship between oil and most of the European markets. More so the results show spillovers volatility between returns in oil price and stock markets. Crude oil price has significant positive impact on the performance of listed oil and gas firms in Western Europe. Musawa and Mwaanga (2017) employed descriptive statistics, Auto Regression Distribution Lag bound test, and Vector Auto Correction base cointegration Model to analyse data generated, in assessing the effect of commodity prices, interest rate and exchange rate on the performance of Zambian stock exchange from 2004 to 2016. The results have it that exchange rate, interest rate, copper and oil price jointly have long run and short run effect on the Zambian stock market. But on the individual variables, interest rate and copper price have long run significant effect on the Lusaka Stock Market, though in a short run, only copper price and exchange rate have immediate effect on the Lusaka Stock Market.

Odubuasi (2016) investigated the effect of exchange rate fluctuation on the manufacturing company's performance in Nigeria covering 2005 to 2014. He set out four hypotheses to help achieve the objective of the study. Ex post facto research design was employed and secondary data was gathered from the firms' annual report and CBN statistical bulletin, wherein multiple regression analytical technique was employed. The findings indicate that exchange rate has no significant effect on all the dependent variables but the effect is positive on Net profit margin, return on assets and return on equity but is negative on earnings per share. 
European Journal of Accounting, Auditing and Finance Research

Vol.8, No. 6, pp.28-45, May 2020

Published by ECRTD-UK

Print ISSN: 2053-4086(Print), Online ISSN: 2053-4094(Online)

Ekinci (2016) investigated the effect of credit and market risk on the bank performance in Turkey for fourteen years using weekly data. In a view to unravel a better understanding on the forces of interest rate, foreign exchange rate and credit risk on bank performance, they employed time series data and used generalized autoregressive conditional heteroscedastic approach in their analysis. The result indicate that credit risk and foreign exchange rate have positive and significant effect whereas interest rate has positive and no significant effect on the performance of banking sector in Turkey. Additionally, they found that credit risk, foreign exchange rate, interest rate risks have a positive and significant effect on the conditional bank stock return volatility.

Nwandu (2016) investigated the impact of rising interest rate on the performance of the Nigerian manufacturing sector for thirty five years, covering 1981 to 2015. The study employed ex post facto research design and generated data from the Central Bank of Nigeria Statistical Bulletin for the relevant years, wherein maximum lending rate was used as the exogenous variable, average manufacturing capacity utilization and contribution of manufacturing sector to GDP were the endogenous variables. The data was analysed using Ordinary Least Square (OLS) regression after it was tested for stationarity, though the result of the stationary test was not shown. The regression result thereof indicated that that the rising interest rate in Nigeria has a negative effect and insignificant effect on the contribution of the manufacturing sector to GDP. More so, the rising interest rate also has a negative and insignificant effect on the average capacity utilization of the Nigerian manufacturing sector.

Muriithi, Muturi and Waweru (2016) examined the challenges posed by market risks on financial performance of commercial banks in Kenya for the periods covering 2005 to 2014 financial year. They used financial leverage, interest rate risk and foreign exchange exposure as the parameter for measuring exogenous variable. Time series cross sectional research design was employed and secondary data was for the forty three (43) registered commercial banks in Kenya, descriptive statistics, correlation analysis and regression of ordinary least square (OLS) were used for analysing the data. The result shows that financial leverage, interest rate and foreign exchange exposure have significant and inverse relationship with bank profitability. The study therefore recommends that commercial banks should be using financial instruments like financial derivative and activeness in derivative markets to mitigate against market risks and also to monitor the financial leverage so as to reduce the financial risk.

Similarly, Alao and Oloni (2015) investigated the effect of commodity price changes on firms' value of Drink service industry on the stock exchange market in Nigeria. Using descriptive survey design, they collected secondary data from 11 firms on food and drink sector from 2009 to 2013. The independent variable, Commodity prices was represented by revenue, cost of sales and stock price whereas the dependent variable firm value was proxy with earnings per share, earnings before interest and tax and assets turnover. Applying correlation and regression analysis on the data gathered, they found that the commodity prices indicators have positive and significant relationship with firm value which was represented by revenue, cost of sales and stock prices.

Helhel (2015) conducted study on foreign exchange rate exposure and its determinants on performance of manufacturing firms in Turkey. The study used the financial statements of 
European Journal of Accounting, Auditing and Finance Research

Vol.8, No. 6, pp.28-45, May 2020

Published by ECRTD-UK

Print ISSN: 2053-4086(Print), Online ISSN: 2053-4094(Online)

thirty seven manufacturing firms traded on the Istanbul Stock Exchange from 2005 to 2014. Jorion's regression model of (1990) was employed to find out the cause and effect relationship between the dependent variable and independent variables. The results show that exchange rate fluctuation is significantly affected by export ratio and the size of assets, while the age of the firm does not significantly affect exchange rate.

Ogundipe, Ojeaga and Ogundipe (2014) examined the relationship between oil price and exchange rate volatility in Nigeria from 1970 to 2011.they sued Johansen estimation technique for the determination of cointegration rank of their model and vector error correction model to ascertain the possibility of error correction in the long run equilibrium path, Augmented Dickey Fuller (ADF) and Phillips Perron tests were applied in determining the stationarity of the time series data generated. Their results show that a proportionate change in oil price leads to a more than proportionate change in exchange rate volatility in Nigeria; which implies that exchange rate is susceptible to changes in oil price.

Norhafiza, Sabariah and Rusmawati (2014) in a bid to determine the impact of commodity prices, interest rate and exchange rate on the stock market performance of Malaysian economy, gathered monthly data from December 1997 to September 2012 and represented one the independent variables (commodity price) with price of palm oil, price of crude oil and price of gold. They employed cointegration bound test regression approach for the model estimation after they applied Augmented Dickey Fuller (ADF) for test of unit root. Their results shown on the long run that there were significant negative relationships between the stock market index and interest rate, as well as the exchange rate at $1 \%$ and 5\% significant level. Also oil price had a significant positive influence on the stock market index. On the short run, the results indicate that a significant negative relationship between the interest rate, exchange rate and stock market index at $1 \%$ significant.

Enyaah (2011) conducted an analysis on the effect of interest rate and exchange rate changes on the stock market return on Ghana stock exchange market covering 2000 to 2010. Time series data was collected from Bank of Ghana website and was tested for stationarity using Augmented Dickey Fuller test, Ordinary Least Square and Vector error correction model were applied in data analysis. The results indicate that long run equilibrium and causal relationship exists between the independent variable and dependent (interest rate and exchange rate). On the short run, the effect of interest rate and exchange rate movements on the return on Ghana stock exchange is nearly imaginary.

\section{SUMMARY OF REVIEWED LITERATURE}

The related literature reviewed on this topic, effect of market risk on firm performance, has shown that scanty literature exists on the topic. Just few authors had researched on the topic which includes; Ekinci (2016) in Turkey who proxy market risk with only interest rate risk and exchange rate risk, Muriithi, Muturi and Waweru (2016) in Kenya proxy market risk with financial leverage, interest margin and exchange rate risks, though financial leverage is a measure of financial risk not market risk, Norhafiza, Sabariah and Rusmawati (2014) in Malaysia used three of the four market risks; commodity price, interest rate and exchange rate and Musawa and Mwaanga (2017) in Zambia used three of the four market risk components; commodity prices, interest rate and exchange rate. The literature review shows that only few 
studies have been done on the topic in Africa and particularly Nigeria especially as it regards using the four components of the market risks together to know how they will collectively influence firms' performance, therefore this becomes the gap in literature that this current study wants to fill.

\section{METHODOLOGY}

The study used causal research design to enable establishment of cause and effect relationship that existed between the dependent and the independent variables. The study covered all the twelve firms under the Oil and Gas sector of Nigerian economy quoted on the Nigerian Stock Exchange at 2019 (www.nse.com), for the periods covering 2014 to 2018. Nigeria economy fell into recession in 2015. Hence, our choice of 2014 as a baseline is to cover adequately the recession periods. Secondary data were used for the study and they were generated from the Central Bank of Nigeria (CBN) Statistical Bulletin, National Bureau of Statistics, and the financial statements of the firms studied. The researchers employed descriptive statistics, Pearson correlation was used to test for the degree of association among the variables, Durbin Waston test was used to test for autocorrelation, Ordinary Least Square (OLS) regression analysis was used to determine the cause-effect relationship between the dependent and the independent variables.

\section{Model Specification}

A regression model was built to suit the variables under study and it presented as below;

ROA $=\mathrm{f}($ INTR, XCHR, COMP, EQUP $)$

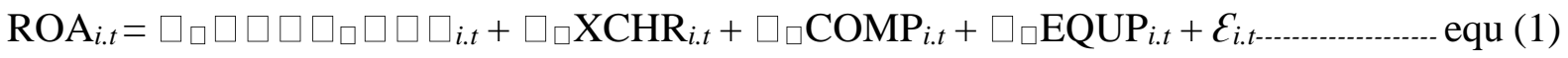

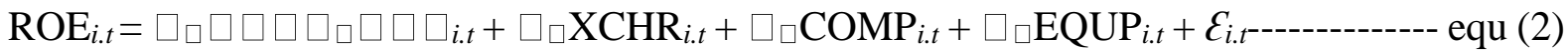

Where;

ROA $=$ Return on Assets

ROE $=$ Return on Equity

INTR $=$ Interest Rate

EXCR $=$ Exchange Rate

$\mathrm{COMP}=$ Commodity Price

$\mathrm{EQUP}=$ Equity Price

$\square \square \square \square \square$ The model constant or the intercept

$\square_{\square \square}=$ Coefficient of the independent model

$\varepsilon_{i . t}=$ Error term 
European Journal of Accounting, Auditing and Finance Research

Vol.8, No. 6, pp.28-45, May 2020

Published by ECRTD-UK

Print ISSN: 2053-4086(Print), Online ISSN: 2053-4094(Online)

\begin{tabular}{|c|c|c|c|c|c|}
\hline & ROA & ROE & EXCR & EQUTP & СОМР \\
\hline Mean & 0.318667 & 1.001067 & 70.234000 & $0.096000 \quad 0.373333$ & 0.726000 \\
\hline Median & 0.205000 & 0.820000 & 0.200000 & 0.0900000 .360000 & 0.550000 \\
\hline Maximum & 1.230000 & 2.780000 & 0.450000 & 0.1300000 .910000 & 1.230000 \\
\hline Minimum & 0.040000 & 0.180000 & 0.050000 & 0.0700000 .090000 & 0.380000 \\
\hline Std. Dev. & 0.284828 & 0.679648 & 0.158630 & 0.0217220 .136141 & 0.339687 \\
\hline Skewness & 1.653484 & 1.229926 & 0.202197 & 0.4034071 .376126 & 0.447613 \\
\hline Kurtosis & 5.152803 & 3.786265 & 1.374796 & 1.7636746 .230398 & 1.446154 \\
\hline Jarque-Bera & 38.92650 & 16.67271 & 7.012056 & 5.44862745 & 8.039666 \\
\hline Probability & 0.000000 & 0.000240 & 0.030016 & 0.0655910 .000000 & 0.017956 \\
\hline Sum & 19.12000 & 60.06400 & 14.04000 & 5.76000022 .40000 & 43.56000 \\
\hline Sum Sq. Dev. & 4.786493 & 27.25338 & 1.484640 & 0.0278401 .093533 & 6.807840 \\
\hline Uoservalon & & & 00 & 60 & 60 \\
\hline
\end{tabular}

Source: Researchers summary (2019) of e-view 8.5

The study observed from the descriptive statistics result that the selected firms have average performance 0.318 and 1.001 respectively for Return on Assets and Return on Equity model respectively. The maximum and minimum value of $1.23,0.2 .78$ and $0.04,0.180$ for ROA and ROE model respectively. This reveals that the Oil and Gas companies used have positive performance over the period of the study. Exchange rate changes have a mean value of 0.234 , maximum values 0.450 and minimum values are 0.050 respectively. The difference between the mean, maximum and minimum value shows that exchange rate fluctuate widely within the period of the study. This fluctuation will have serious impact on the activities of the Oil and Gas companies who deals majorly on export and import.

The result of the Interest rate change shows that there is no much variation in interest rate over the period. The study also observed that Interest rate change is normally distributed at $5 \%$ level within the period of the study. The mean value of the equity price change result shows that the equity price of Oil and Gas firms varied widely within the period of the study. The difference between the maximum value and minimum value confirms the wide changes or variation in equity prices of the Oil and Gas firms used. The result of the Crude oil prices rate change shows that change in crude oil price over the period is relatively stable, there is no much change in the price of crude oil over the period of the study. All the variables are normally distributed and the distribution is significance. The result means that all the explanatory variables are normally distributed, hence no presence of outlier. 
European Journal of Accounting, Auditing and Finance Research

Vol.8, No. 6, pp.28-45, May 2020

Published by ECRTD-UK

Print ISSN: 2053-4086(Print), Online ISSN: 2053-4094(Online)

Correlation analysis

\begin{tabular}{lclllllr} 
& $R O A$ & $R O E$ & EXCR & \multicolumn{1}{c}{ INTR } & \multicolumn{1}{c}{ EQUTP } & \multicolumn{1}{c}{ CRUOP } \\
ROA & 1.000000 & -0.208212 & 0.056690 & -0.037311 & 0.080105 & 0.097677 \\
ROE & -0.208212 & 1.000000 & 0.028092 & -0.071780 & -0.092093 & -0.086502 \\
EXCR & 0.056690 & 0.028092 & 1.000000 & -0.756701 & -0.145114 & -0.067263 \\
INTR & -0.037311 & -0.071780 & -0.756701 & 1.000000 & 0.042984 & 0.350614 \\
EQUTP & 0.080105 & -0.092093 & -0.145114 & 0.042984 & 1.000000 & -0.265459 \\
CRUOP & 0.097677 & -0.086502 & -0.067263 & 0.350614 & -0.265459 & 1.000000
\end{tabular}

Source: Researchers summary (2019) of e-view 8.5

The correlation analysis result shows that ROA and ROE has negative relationship. This reveals that both Return on Assets and Return on Equity as measures of performance are not interchangeable as they reveal different aspect of performance. Return on assets has a negative relationship with interest rate change, and positive relationship with exchange rate change, interest rate change, and crude oil price change. This reveals that increase in interest rate change will lead to lower performance measured by Return on Assets. Return on Equity has negative relationship with equity price change, interest rate change, and crude oil price change. The negative relationship reveals that the higher the equity price change, interest rate change, and crude oil price change, the lower the firm performance of Oil and Gas firms will tend to be. While the positive relationship between firm performance and exchange rate change indicates that the higher the exchange rate changes the higher the firm performance of those Oil and Gas firms. The result shows that no two explanatory variables were perfectly correlated. This indicates the absence of multi-colinearity problem in the model used for the analysis.

\section{Hypotheses Testing \\ Regression analysis table \\ Dependent Variable: ROA \\ Method: Panel Least Squares \\ Cross-sections included: 12}

\begin{tabular}{|c|c|c|c|c|}
\hline Variable & Coefficient & t Std. Error & t-Statistic & Prob. \\
\hline$C$ & 0.208349 & 0.360090 & 0.578603 & 0.5652 \\
\hline$E X C R$ & 0.846286 & 0.386668 & 2.188664 & 0.0152 \\
\hline INTR & -1.052378 & 2.998994 & -0.350910 & 0.7270 \\
\hline EQUTP & 0.272691 & 0.292421 & 0.932530 & 0.3551 \\
\hline СOMP & 0.135964 & 0.130152 & 1.044659 & 0.3008 \\
\hline$R$-squared & 0.430735 & \multicolumn{2}{|c|}{ Mean dependent var } & 0.318667 \\
\hline Adjusted R-squared & 0.389757 & \multicolumn{2}{|c|}{ S.D. dependent var } & 0.284828 \\
\hline S.E. of regression & 0.290435 & \multicolumn{2}{|c|}{ Akaike info criterion } & 0.444780 \\
\hline Sum squared resid & 4.639379 & \multicolumn{2}{|c|}{ Schwarz criterion } & 0.619308 \\
\hline Log likelihood & 118.3492 & \multirow{2}{*}{\multicolumn{2}{|c|}{$\begin{array}{l}\text { Hannan-Quinn criter } \\
\text { Durbin-Watson stat }\end{array}$}} & 0.513048 \\
\hline$F$-statistic & 8.436011 & & & 1.968442 \\
\hline $\operatorname{Prob}(F$-statistic $)$ & 0.000014 & & & \\
\hline
\end{tabular}

Source: Researcher's analysis from E-view 8.5 
European Journal of Accounting, Auditing and Finance Research

Vol.8, No. 6, pp.28-45, May 2020

Published by ECRTD-UK

Print ISSN: 2053-4086(Print), Online ISSN: 2053-4094(Online)

Regression analysis: Return on equity model

Dependent Variable: ROE

Method: Panel Least Squares

Cross-sections included: 12

\begin{tabular}{|c|c|c|c|c|}
\hline \multirow{2}{*}{$\begin{array}{l}\text { Variable } \\
\text { C }\end{array}$} & \multicolumn{2}{|c|}{ Coefficient Std. Error } & \multirow{2}{*}{$\begin{array}{c}t \text {-Statistic } \\
1.884268\end{array}$} & \multirow{2}{*}{$\begin{array}{l}\text { Prob. } \\
0.0648\end{array}$} \\
\hline & 1.625224 & 0.862523 & & \\
\hline$E X C R$ & -1.405895 & 0.526183 & -2.671875 & 0.0024 \\
\hline INTR & -2.142456 & 0.283476 & -7.557804 & 0.0000 \\
\hline EQUTP & -0.609955 & 0.700434 & -0.870825 & 0.3876 \\
\hline СОМР & -0.196398 & 0.311752 & -0.629983 & 0.5313 \\
\hline 10.04 & & $\mathrm{Mea}$ & & 1.001067 \\
\hline Adjusted R-squared & 0.447724 & S.D. & endent & 0.679648 \\
\hline S.E. of regression & 0.695677 & Akaike & ffo criterion & 2.191793 \\
\hline Sum squared resid & 26.61815 & Schwarz & criterion & 2.366321 \\
\hline Log likelihood & 260.7538 & Hannar & Quinn criter. & 2.260060 \\
\hline$F$-statistic & 17.32813 & Durbin & Watson stat & 1.583517 \\
\hline $\operatorname{Prob}(F$-statistic $)$ & 0.000000 & & & \\
\hline
\end{tabular}

In table 4.3 above, the study observes from the Return on Assets model result that the R-sq is 0.43 and $\mathrm{R}$-sq (adj) is 0.39 . This value indicates that market risk variables used explain about 39 percent changes in performance of Oil and Gas firm used in the study. The F-statistics value of 8.43 , and its probability value of 0.000 , shows that the regression model is well specified and the specification is statistically significant at $1 \%$ levels. The Durbin Watson value reveals the absence of autocorrelation in our model.

Return on Equity model: The study observed from the firm performance model result that the $\mathrm{R}$-sq and R-sq (adj) are 0.523 and 0.448 respectively. This value indicates that market risk variables used explain about 44.8 percent changes in performance of Oil and Gas firm used in the study. The F-statistics value of 17.33, and its probability value of 0.000 , shows that the Return on Equity regression model is well specified and the specification is statistically significant at $1 \%$ levels. The Durbin Watson value reveals that there is no presence of autocorrelation in our model.

Hypotheses 1: Exchange rate change has no significant effect on firm performance The analysis result showed a coefficient value of 0.846 and -1.406 for Return on Assets and Return on Equity model respectively. This reveals that exchange rate has positive effect on firm performance measured by Return on Asset and negative effect the level of firm performance measured by return on equity of quoted Oil and Gas firms. This also indicates that higher Exchange rate can lead to higher Return on Asset and lower Return on Equity. The probability value however shows that the effect of exchange rate on performance (Return on Assets and Return on Equity) of Oil and Gas companies in Nigeria is statistically significant. Based on the analysis result, the study rejects the null hypothesis and accepts the alternate hypothesis, the study therefore concludes that, Exchange rate has significant effect on the 
European Journal of Accounting, Auditing and Finance Research

Vol.8, No. 6, pp.28-45, May 2020

Published by ECRTD-UK

Print ISSN: 2053-4086(Print), Online ISSN: 2053-4094(Online)

performance of Oil and Gas companies in Nigeria. This result is supported by the findings of Ekinci (2016) and Harley (2018) whose studies indicated that foreign exchange rate fluctuations have significant and positive effect on the financial performance of firms. On the other hand, exchange rate change has inverse effect on ROE, an indication that a unit increase in exchange rate would cause 1.41 unit changes in ROE, though it is significant. Notwithstanding, this result conforms to the finding of Norhafiza, Sabariah and Rusmawati (2014) and Sabariah and Rusmawati (2014) who concludes that exchange rate changes have significant negative effect on stock return

\section{Hypothesis 2: Crude oil price change has no significant effect on firm performance}

The analysis result showed a coefficient value of 0.136 and -0.196 . The coefficient value reveals that crude oil price change positively affects Return on Assets and negatively affects Return on Equity. This reveals that higher crude oil price changes lead to higher Return on Assets and lower Return on Equity (performance) among Oil and Gas firms. The probability value of Return on Assets and Return on equity shows that the effect of crude oil price change on the performance of Oil and Gas companies in Nigeria is not statistically significant. Based on the analysis result, the study rejects the alternate hypothesis and accepts the null hypothesis it therefore concludes that, crude oil price change has no significant effect on the performance of Oil and Gas companies in Nigeria. The result is consistent with the result of Norhafiza, Sabariah and Rusmawati (2014) that crude oil price has no significant effect on stock market performance

\section{Hypothesis 3: Equity price change has no significant effect on firm performance}

The analysis result shows a coefficient value of 0.273 and -0.610 . The negative coefficient shows that equity price change negatively affects the level of Return on Equity, while the positive coefficient value indicates that equity price change positively affects the Return on Assets of Oil and Gas firms. However the probability value shows that the effect of equity price change on Return on Assets and Return on Equity is not statistically significant for both models. Based on the analysis result, the study rejects the alternate hypothesis and accepts the null hypothesis, it therefore concludes that, equity price change has no significant effect on the performance of Oil and Gas sector in Nigeria.

\section{Hypothesis 4: Interest rate change has no significant effect on firm performance}

The analysis result showed a coefficient value of -1.052 and -2.142, a P-value of 0.727 and 0.000 for Return on Assets and Return on Equity model respectively. The coefficient value shows that interest rate change has a negative effect on Return on Assets and on Return on Equity of Oil and Gas firms. The value shows that increase in interest rate change can decrease the level of firm Return on Assets and Return on Equity among Oil and Gas firms. The probability value reveals that the effect of interest rate change on Return On Assets of Oil and Gas sector in Nigeria is not significant but is significant on Return On Equity. Based on the result, the study rejects the null hypothesis and accepts the alternate hypothesis, it therefore concludes that, interest rate change has significant effect on the firm performance of Oil and Gas sector in Nigeria. However, the finding conforms to that of Muriithi, et al (2016), Papa (2014), and Khan and Sattar (2014) that interest rate have significant effect on firm performance. Though the finding disagrees with the result of the Eknici (2016) and Nwandu (2016) who found that interest rate have insignificant effect on firm performance. 
European Journal of Accounting, Auditing and Finance Research

Vol.8, No. 6, pp.28-45, May 2020

Published by ECRTD-UK

Print ISSN: 2053-4086(Print), Online ISSN: 2053-4094(Online)

\section{CONCLUSION AND RECOMMENDATION}

\section{Conclusion}

Market risk is a serious challenge facing survival of companies in Nigeria. The uncertainty and undiversifiability of the market risk has instigated this study, to investigate how Oil and Gas has fared in the turbulence of this market risk. The four major components of market risk (interest rate change, exchange rate change, commodity price change and equity price change) were the variables used to represent the market risk. The firm performance on the other hand was proxied with ROA and ROE. The study empirically sought for understanding between these market risks and firm performance. It noted that whenever the interest rate is meant to be increased, that performance of Oil and Gas firms would drop, owning to the fact that servicing charges on the borrowed monies would be very high. Furthermore, the price of shares in the market should not be seen as factor that determines the profitability of Oil and Gas sector. The market risks really have a dominant role in determining the financial performance of Oil and Gas sector in Nigeria.

\section{Recommendation}

In line with the findings from the result of the analysis, the study makes the following recommendation;

1. As a way to put control on the volatility of exchange rate, the firms can use hedging to guard against the effect of exchange rate fluctuation on performance of Oil and Gas sector.

2. Less attention should be given to crude oil price as its price change has no significant effect on firm performance, though the Oil and Gas firms can make a policy of an acceptable profit margin for their sales. This can make them adjust appropriately to changes in crude oil price.

3. The firms should shift attention from the equity price and concentrate more on improving its profit position to pay dividend as equity price responds to market information more.

4. Since increase in interest rate lowers profitability of Oil and Gas firms, the government should ensure a reduced interest rate legislation so that firms within the economy can thrive, in that case the economy grows.

\section{REFERENCES}

Adesoji, F. (2016). Perspectives on the Nigerian economic recession. Centre for Allied Research and economic Development: Ibadan Nigeria.

Agubata, S.N., \& Odubuasi, A.C (2018). Effect of exchange rate fluctuation on the financial performance of Nigerian manufacturing firms: Evidence from food beverage and tobacco sector. International Journal of commerce and Management Research, 4(4), 56-61.

Alao, E.M., \& Oloni, E.F. (2015). The effect of commodity price changes on firm value: Study of food and drinks service industry in Nigeria. European Journal of Accounting and Finance Research, 3(6), 26-38.

Bagirov, M., \& Mateus, C. (2017). Oil price, stock markets and firm performance: Evidence from Europe. DOI: 10.2139/ssrn.2978119 
European Journal of Accounting, Auditing and Finance Research

Vol.8, No. 6, pp.28-45, May 2020

Published by ECRTD-UK

Print ISSN: 2053-4086(Print), Online ISSN: 2053-4094(Online)

Darko, G., \& Kruger, J. (2017). Determinants of oil price influence on profitability measure of oil and gas companies: A panel data perspective. International Journal of Economics, Commerce and Management,5(12), 993 - 1006.

Ekinci, A. (2016). The effect of credit and market risk on bank performance: evidence from Turkey. International Journal of economics and Financial Issues, 6(2), 427 - 434.

Enekwe,C.I., Ordu, M.M., \& Nwoha, C. (2013). Effect of exchange rate fluctuations on manufacturing sector in Nigeria. European Journal of Business and Management, $5(22), 67-73$.

Farayibi, A.O (2016). Perspectives on the Nigerian economic recession: Policy briefs. Center for Allied Research and Economic Development, Ibadan, Oyo State-Nigeria.

Farooki, M. Z. \& Kaplinsky, R. (2011). The Impact of China on Global Commodities: The Disruption of the World's Resource Sector, London: Routledge.

Gilchris, M. (2013). Influence of bank specific and macroeconomic factors on the profitability of twenty five commercial banks in Pakistan during the period 20072011. American Journal of Business and Finance, 3(2), 1-28.

Grimes, A. (2006). A smooth ride: Terms of trade, volatility and GDP growth. Journal of Asian Economy, 17(4), 584-600.

Gyasi, A.K. (2016). Commodity price shocks and African stock markets: Evidence from Ghana. Proceeding of the First American Academic Research Conference on Global Business, Economic, Finance and Social Sciences (New York Conference). www.globalbizresearch.org

Harley, T.W. (2018). An empirical investigation of the impact of exchange rate fluctuations on the performance of selected listed firms in Nigeria. Journal of Business Management and Economic Research, 2(3), 1-10.

Hayes, K.C. (2013). How interest rate impacts on bottom lines: A look at history. Value Walk. http://www.valuewalk.com/2013/interest/rate/banks/earnings/good

Helhel, Y. (2015). Foreign exchange rate exposure and its determinants on performance of manufacturing firms in Turkey. Research Journal of finance and Accounting, 6(12), 80-87.

Hull, J.C. (2015). Risk management and financial institution. 4ed New Jersey: John Wiley \& Sons.

Ihsan, H., Rashid, A., \& Naz, A. (2018). Exchange rate exposure and firm value: An assessment of domestic versus multinational firms. The Lahore Journal of Economics, 23(1), 51-77.

Ildirar, M., \& Iscan, E.(2016). The interaction between stock prices and commodity prices: Eastern Europe and Central Asia case. International Journal of Economics and financeStudies, 82), $94-103$.

Irungu, P.M. (2013). The effect of interest rate spread on financial performance of banks in kenya. An M.Sc research project submitted to the University of Nairobi.

Irungu, P.M., \& Kamau, S.G (2013). Effect of financial indicators on market price of shares in commercial banks of Kenya. International Journal of Management \& Business Studies,3(3), $57-60$.

Kanchu, T., \& Kumar, M. (2013). Risk management in banking sector. International Journal of Marketing, Financial Services and Management Research, 2(2), 145-153. 
European Journal of Accounting, Auditing and Finance Research

Vol.8, No. 6, pp.28-45, May 2020

Published by ECRTD-UK

Print ISSN: 2053-4086(Print), Online ISSN: 2053-4094(Online)

Khan, W.A., \& Sattar, A. (2014). Impact of interest rate changes on the profitability of major commercial banks in Pakistan. International Journal of Accounting and Financial Reporting, 4(1), 142-154.

Kithinji, M.A (2010). Credit risk management and profitability of commercial banks in Kenya. Published Thesis of School of Business, University of Nairobi.

Kose, M. A. (2002). Explaining business cycle in small open economies - How much do world Price matter? Journal of International Economics, 56(2), 299-327.

Legat, C.C., \& Nyandema, D.M. (2016). The influence of foreign exchange rat fluctuation on the financial performance of commercial banks listed at the Nairobi securities exchange. British Journal of Marketing Studies, 4(3), 1-11.

Levy, M., \& Roll, R. (2010). The market portfolio may be mean or variance efficient after all. Review of Financial studies, 23(6), 2464 - 2491.

Lintner, J. (1965). The valuation of risk assets on the selection of risky investments in stock portfolios and capital budgets. Review of economics and Statistics, 47, 13-37.

Malik, M.F., Shehzed, K., Khan, M.I., \& Faisal, K. (2014). Interest rate and its effect on banks profitability. Journal os Applied Environmental and Biological Sciences, 4(8s), 225-229.

Maranga, O.W., \& Nyakundi, N.E (2017). Effect of interest rate on business investment performance of selected sommercial banks in Kisii town Kenya. Journal of Accounting and Marketing, 6:1 DOI: 10.4172/2168-9601.1000221

Menaje, P. (2012). Impact of selected financial variables on share prices of publicly listed firms in the Philippines. American International Journal of Contemporary Research, 2(9), 34-43.

Monad, B., Giorgino, M., \&Modolini, I. (2013). Rational for corporate risk management : A critical literature review. Bepartment of Management, Economics and Industrial Engineering

Mongale, I.P., \& Eita, J.H. (2014). Commodity prices and stock market performance in South Africa. Corporate Ownership and Control, 11(4), 370 - 375.

Muriithi, J.G., Muturi, W.M., \& Waweru, K.M. (2016). The effect of market risk in financial performance of commercial banks in Kenya. Journal of Finance and Accounting, $4(4), 225-233$.

Musawa, N., \& Mwaanga, C. (2017). The effect of commodity prices on stock market performance in Zambia. American Journal of Economics, 7 (5) 259- 262.

Musawa, N., \& Mwaanga, C. (2017). The impact of commodity prices, interest rate and exchange rate on stock market performance: Evidence from Zambia. Journal of Financial risk Management, 6, 300 - 313. https://doi.org/10.4236/jfrm.2017.63022.

Mustafa, K., \& Nishat, M. (2006). Volatility of exchange rate and export growth in Pakistan: The structure and independence in regional markets. Working Paper of State Bank of Pakistan.

Musyoki, D. (2011). Changes in the share prices as a predictor of accounting earnings for financial firms listed on the Nairobi security exchange. International Journal of Business and Public Management, 2 (2), 1-11.

Namasake, W.K. (2016). The effect of market risk on the financial performance of commercial banks in Kenya. Unpublished M.Sc project submitted to School of Business, University of Nairobi. 
European Journal of Accounting, Auditing and Finance Research

Vol.8, No. 6, pp.28-45, May 2020

Published by ECRTD-UK

Print ISSN: 2053-4086(Print), Online ISSN: 2053-4094(Online)

Ngugi, R. (2004). Determinants of interest rates spread in Kenya, Nairobi. Kenya Institute for Public Policy Research and Analysis.

Noor, J.A.M., \& Abdalla, A.I. (2014). The impact of financial risks on the firm's performance. European Journal of Business and Management, 6(5), 97 - 101.

Norhafiza, N., Sabariah, N., \& Rusmawati, I. (2014). The impact of commodity prices, interest rate and exchange rate on stock market performance: An empirical analysis from Malaysia. Malaysian Management Journal, 18, 39 -52.

Nwandu, E. (2016). Impact of rising interest rate on the performances of the Nigerian manufacturing sector. European Journal of Business and Management, 8(10), 125-134.

Odularu, G.O (2008). Crude oil and the Nigerian economic performance. Oil and Gas business, 1-30 http://www.statista.com.

Ogiri, I.H., Amadi, S.N., Uddin, M.M., \&Dubon, P. (2013). Oil price and stock market performance in nigeria: An empirical analysis. American Journal of social and Management Sciences, 4(1), 20 - 41.

Ogunbiyi. S.S \& Ihejirika, P.O (2016). Interest rate and deposit money banks profitability nexus: the Nigerian experience. Ariabian Journal of Business and Management Review (OMAN chapter), 3(11), 133-148.

Okereke, U.J. (2017). Foreign exchange rate dynamics and manufacturing firms' performance in Nigeria. International Journal of Humanities and Social Science Invention, 6(9), 9-14.

Oladipupo, A.O. \& Anotaniyohuwo, F.O. (2011). Impact of exchange rate on balance of payment in Nigeria. African research Review: An International Multidisciplinary Journal, Ethiopia, 5(4), 73 - 88.

Opaluwa, D., Umeh, J.C., \& Ameh, A.A. (2010). The effect of exchange rate fluctuation on the Nigerian manufacturing sector. African Journal of Business Management, 4(4), $2994-2998$.

Papa, V. (2014). The great unwind: What will rising interest rate mean for banks risk exposure? Market integrity insights

Parlak, D., \& Ilhan, H. (2016). Foreign exchange risk and financial performance: the case of Turkey. International Review of Economics and Management, 4(2), 1-15.

Ramos, S.B., \& Veiga, H. (2011). Risk factors in oil and gas industry returns: International evidence. Energy Economics, 33(2011) 525 - 542.

Risman, A., Salim, U., Sumiati, S., \& Indrawati, N.K. (2017). Commodity prices, exchange rate and investment on firm's value mediated by business risk: A case from Indonesian stock exchange. European Research Studies Journal, 20 (3A), 511 - 524.

Rodriguez-Morenno, M., \& Pena, J.I. (2013). Systematic risk measures: the simpler the better. Journal of Banking and Finance, 37(6), 1817 - 1831.

Rossi, M. (2016). The capital assets pricing model: A critical literature review

Saeed, S. (2012). Impact of market economic factors on the returns of oil and gas sector in Pakistan. International Journal of Contemporary Business studies, 3(2), 15-25.

Shido-Ikwu, B.S. (2017). Economic recession in Nigeria: A case for government intervention. International Journal off Economic and Management Studies (SSRGIJEMS), 4(6), 48-51. 
European Journal of Accounting, Auditing and Finance Research

Vol.8, No. 6, pp.28-45, May 2020

Published by ECRTD-UK

Print ISSN: 2053-4086(Print), Online ISSN: 2053-4094(Online)

Ud Din, N., \& Zulfiquar (2015). Inflation, interest rate and firm's performance: The evidences from textile industry of Pakistan. International Journal of Arts and Commerce, 4(2), 111-115.

Vegh, C., Morano, L., \& Friedheim, D. (2017). Between a rock and a hard place: The monetary policy dilemma in Latin America. Semiannual Report of International Bank for Reconstruction and Development/ The World Bank.

Wattanatorn, W., \& Kanchanapoom, T. (2012). Oil prices and profitability performance: Sector analysis. Procedia-Social and Behavioral Sciences, 40 (2012), 763 - 767. 